\title{
Is hepatojugular reflux a good predictor of heart failure with preserved ejection fraction?
}

\author{
Guilherme Cristianini Baldivia" \\ (iD) João Vitor Moraes Pithon Napoli \\ (iD) Josiane Motta e Motta \\ Normando Gomes Vieira Filho' \\ (iD) Heno Ferreira Lopes ${ }^{1,3}$
}

\begin{abstract}
1. Nove de Julho University - UNINOVE, São Paulo, SP, Brasil 2. São Caetano do Sul University - USCS, São Caetano do Sul, SP, Brasil 3. Heart Institute (Incor) of the HCFMUSP, São Paulo, SP, Brasil
\end{abstract}

http://dx.doi.org/10.1590/1806-9282.65.5.592

\section{SUMMARY}

Hypertension may occur with left ventricular (LV) diastolic dysfunction, and the consequence may be symptoms and signs of heart failure (HF). Hepatojugular reflux (HJR), described as a sign of regurgitation of the tricuspid valve, may reflect structural and functional changes of the LV in the hypertensive patient. The signal may be present in the presence of HF. Case: male, 49 years old with uncontrolled blood pressure. Physical examination showed jugular turgescence, HJR, and elevated blood pressure. Complementary exams showed signs of atrial and left ventricular overload in the electrocardiogram and, the echocardiogram showed left atrium volume increase, concentric LV hypertrophy and signs of grade I diastolic dysfunction.

DISCUSSIO: The HIR present correlates with pulmonary artery pressure and probably reflect the increase in central blood volume.

KEYWORDS: Hypertension. Jugular Veins/physiology. Heart failure.

\section{INTRODUCTION}

Systemic arterial hypertension (SAH) is a multifactorial clinical condition characterized by elevated and sustained blood pressure (BP). It is often associated with functional and structural changes of the target organs, such as the left ventricular hypertrophy (LVH). ${ }^{1}$ SAH is one of the most important factors related to congestive heart failure, and cardiac remodeling is a key mechanism of its progression. ${ }^{2}$ LVH can lead to diastolic dysfunction of the left ventricle and is a risk factor for myocardial infarction, both important causes of ventricular systolic dysfunction. The asymptomatic dysfunction of the left ventricle (LV) may culminate with the clinical mani- festation of heart failure (HF), when it exceeds a certain threshold or when other risk factors exist. ${ }^{2}$

The HF is classified using the ejection fraction in $\mathrm{HF}$ with reduced ejection fraction (HFrEF) and HF with preserved ejection fraction (HFpEF). It is known that cardiovascular morbidity and mortality in HFrEF patients improve with clinical treatment. $^{3}$ Mortality in HFpEF patients is high, and it is known that the prognosis is poor. ${ }^{4}$ The early clinical diagnosis of HFpEF may involve the patient's prognosis. Clinical findings such as the hepatojugular reflux (HJR) may reflect structural and functional changes of the left ventricle in pa- 
tients with hypertension, and hypertension may precede HF. $^{5}$

HJR was described by Pasteur ${ }^{6}$ in 1885 as being a sign of tricuspid regurgitation. Subsequently, it was used in the diagnosis of congestive heart failure. ${ }^{7}$ The signal comprises the compression of the hepatic region and the observation of the superficial veins of the neck ${ }^{6}$, i.e., it involves the regurgitation of blood in the jugular vein while applying pressure on the abdomen. ${ }^{8}$ During the HJR examination, one must apply pressure for 10 seconds and observe the jugular vein in the following 15 seconds $^{8}$. When the regurgitation remains high for 10 seconds, the result is considered positive or present.$^{9}$

HJR is present in several clinical conditions, for example, in constrictive pericarditis, in right ventricular infarction, and in restrictive cardiomyopathy. Later it was noted that it could also be present in the dysfunction of the left ventricle when the pulmonary capillary wedge pressure is greater than $15 \mathrm{mmHg}$, characterizing pulmonary hypertension caused by diseases of the left heart. Therefore, this finding may provide relevant clinical information in patients with LV dysfunction.

Echocardiography allows to evaluate the LV dysfunction and the E/e' ratio (ratio between the velocity of the initial transmitral flow and tissue Doppler recorded in the mitral valve ring) has a correlation with the left ventricular end-diastolic pressure (filling pressures) for both high pressures (E/E' $>15)$ and normal pressures $\left(\mathrm{E}^{\prime} / \mathrm{E}^{\prime}<8\right)^{10}$, providing an estimate of the filling pressures of the left ventricle in a non-invasive way. This case report aims to describe the importance of HJR in the evaluation of patients with HFpEF and discuss the possible use of this propaedeutics tool, with greater emphasis on clinical practice.

\section{RESULTS}

\section{Clinical case report}

A man, 49 years old, married, born in Paraíba and residing in São Paulo (capital) for 20 years. Blood pressure of $180 \times 100 \mathrm{mmHg}$ was observed. The patient was advised to seek medical evaluation and later return to service. He reported a diagnosis of hypertension since he was 39 years old and complained of recent onset of evening edema. He reported snoring, dyspnea on moderate exertion, fatigue, and weakness to conduct professional activities. He also reported an adequate intake of salt and denied consuming industrialized products. He also denied alcoholism and smoking.

He takes hydrochlorothiazide $25 \mathrm{mg}$ once a day, atenolol $50 \mathrm{mg}$ once a day, amlodipine $5 \mathrm{mg}$ twice a day, and losartan $50 \mathrm{mg}$ twice a day.

The general physical examination showed: jugular venous distension and HJR (Figure 1) at $45^{\circ}$, BP $160 \times 90 \mathrm{mmHg}$, a cervical circumference of $48 \mathrm{~cm}$, an abdominal circumference of $103.5 \mathrm{~cm}$, a hip circumference of $109 \mathrm{~cm}$, and body mass index $34.5 \mathrm{~kg} / \mathrm{m}^{2}$. The special physical examination showed no changes in the respiratory and cardiovascular examination, except for the HJR. The abdominal, neurological, and muscular exams were also normal. The patient underwent laboratory exams (biochemical) that were within the normal range.

The 12-lead electrocardiogram showed sinus bradycardia, the normal axis (+60) and signs of left atrial and ventricular overload (Morris signal and Cornell index altered). The total abdominal ultrasound showed moderate hepatic steatosis (grade II) and a renal cyst on the left.

The endoscopic examination (esophagogastroduodenoscopy): intense enanthematous pangastritis (the study of Helicobacter pylori using urease test came back positive).

\section{FIGURE 1. HEPATOJUGULAR REFLUX AT $45^{\circ}$}

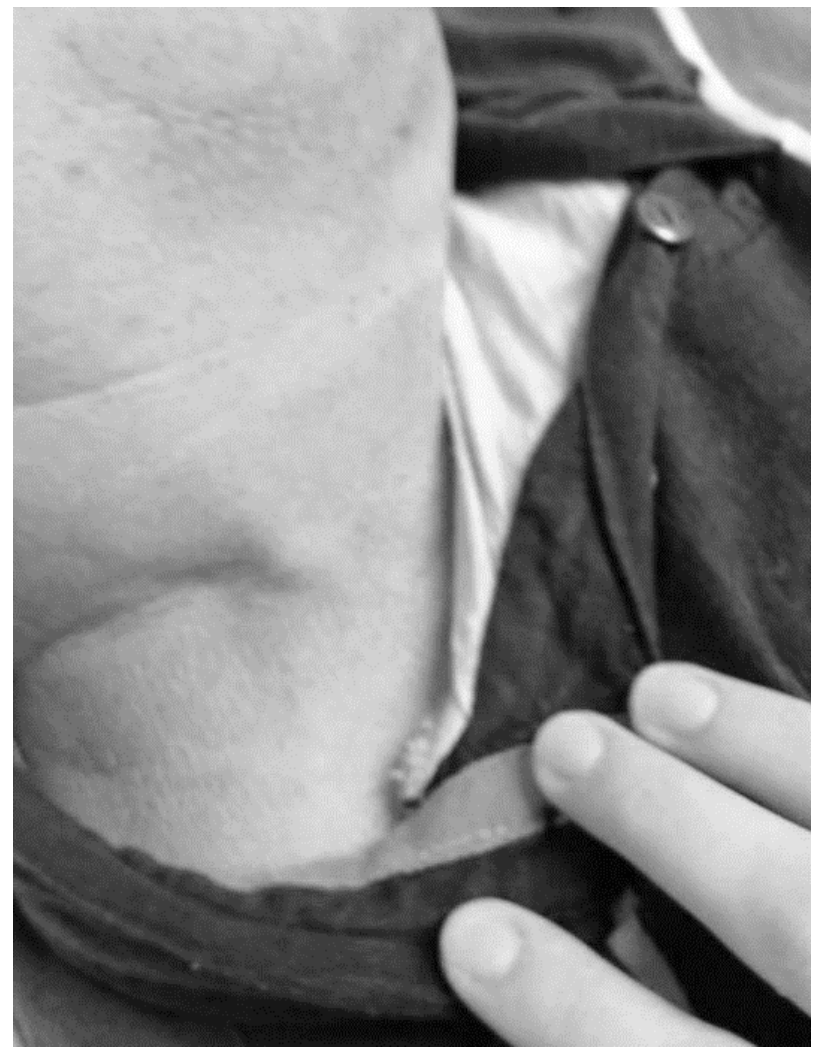


Polysomnography: fragmented sleep and mild obstructive sleep apnea.

The echocardiogram: an increase in left atrial volume, left ventricle with preserved dimensions, an increase in the myocardial thickness with LV mass estimated at $358 \mathrm{~g}$ and mass index of $186 \mathrm{~g} / \mathrm{m}^{2}$, characterizing concentric left ventricle hypertrophy. The left ventricular systolic function was preserved, with an ejection fraction of $70 \%$ and signs of diastolic dysfunction degree I (Figure 2).

\section{DISCUSSION}

HJR may reflect structural and functional alterations of the left ventricle in hypertensive patients. According to Ewy ${ }^{11}$, the positive HJR test correlates with the pressure of the pulmonary arterioles, being probably a reflex of the increased central blood volume. In the absence of right ventricular failure, it has been observed that in some patients with infarction of the right ventricle this test is positive and suggests a pulmonary artery pressure greater than or equal to 15 mmHg."

The impairment of left ventricular function in hypertensive patients is not always of the systolic type. Quite the contrary, in most of the cases the dysfunction is diastolic. The patient presented in this study showed increased left atrial volume, left ventricle with preserved dimensions and increased thickness on the echocardiogram, characterizing concentric hypertrophy of the left ventricle. There are indirect signs of diastolic dysfunction degree I, characterized by the relationship of the E/A $<0.8$ waves; $\mathrm{E}<50 \mathrm{~cm} / \mathrm{s}$ wave; e' $<8 \mathrm{~cm} / \mathrm{s}$ wave (Figure 2) and the $\mathrm{E} / \mathrm{e}^{\prime}=14$ ratio. These echocardiographic findings may justify the presence of HJR.

The HFpEF presumably called diastolic heart failure (DHF) is not fully defined, and there is doubt if it truly represents the clinical features of HF. ${ }^{12}$ It is known that DHF has physiopathological characteristics similar to those of systolic heart failure (SHF), including: severely reduced exercise capacity, neuroendocrine activation and impaired quality of life. ${ }^{13} \mathrm{In}$ a study by Kitzman et al. ${ }^{12}$, the pathophysiology of the DHF and SHF syndromes was evaluated. In this study, the relationship between the mass/volume of the left ventricle in DHF patients was $2.12 \mathrm{~g} / \mathrm{mL}$, and in SHF it was $1.22 \mathrm{~g} / \mathrm{mL}$. In patients with DHF, the septal wall was $13.1 \mathrm{~mm}$ and the posterior, $12.0 \mathrm{~mm}$, while in patients with SHF they were $8.9 \mathrm{~mm}$ and 9.7 $\mathrm{mm}$, respectively. The thickness of our patient's septum was $15 \mathrm{~mm}$, and the wall thickness was $14 \mathrm{~mm}$. The cut-off value for the e/a ratio to characterize diastolic dysfunction is $<0.8$, and the patient presented an e/a ratio $=0.71$. The patient's echocardiographic signs suggested diastolic dysfunction and positive HJR during the physical examination. On the other hand, the patient had no clinical sign or echocardiography finding suggestive of right ventricular dysfunction. This leads us to believe that the HJR present on the physical examination reflects the diastolic dysfunction of the left ventricle. This confirms the findings of the study by Kitzman et al. ${ }^{12}$

During the physical examination, the patient presented jugular venous distension at $45^{\circ}$ and HJR, suggesting elevated cardiac pressures and reduction

FIGURE 2. DIASTOLIC DYSFUNCTION BY TISSUE DOPPLER

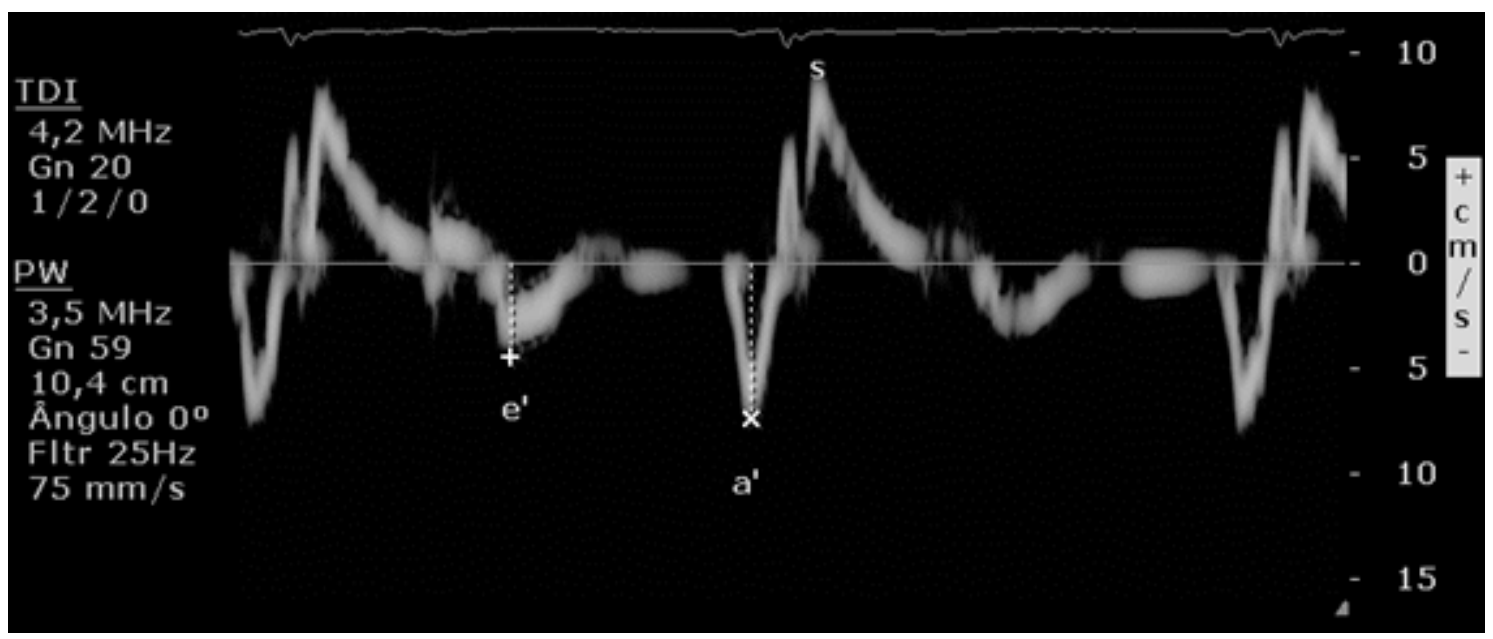


of cardiac performance. In the study by Butman et al. ${ }^{13}, 53$ patients with HF functional class III (NYHA) with LV dysfunction were evaluated. The presence of jugular vein distension at rest or when performing the HJR maneuver resulted in the best combination of sensitivity (81\%), specificity (80\%), and predictive value (81\%) for increased pulmonary capillary wedge pressure ( $\geq 8 \mathrm{mmHg}$ ). One limitation of this study was that the physical examination did not occur simultaneously with the hemodynamic study.

\section{CONCLUSION}

HJR was present in the physical examination of the systemic arterial hypertension stage III patient with heart failure class $\mathrm{C}$ according to the American Heart Association (AHA); HJR was associated with signs of LV diastolic dysfunction on the echocardiography. The findings reinforce the importance of research on HJR in clinical practice. There is a need for further studies to clarify the relationship between HJR and left HF.

\section{RESUMO}

A hipertensão pode cursar com disfunção diastólica de ventrículo esquerdo (VE) e a consequência disso pode ser sintomas e sinais de insuficiência cárdica (IC). O refluxo hepatojugular (RHJ), descrito como sinal de regurgitação da valva tricúspide, pode refletir alterações estruturais e funcionais do VE no paciente hipertenso. O sinal pode estar presente na vigência de IC. Caso: homem, 49 anos compressão arterial não controlada. Ao exame físico apresentou turgência jugular, RHJ e pressão arterial elevada. Os exames complementares mostraram sinais de sobrecarga atrial e de ventrículo esquerdo no eletrocardiograma, e no ecocardiograma foi evidenciado aumento do volume do átrio esquerdo, hipertrofia concêntrica do VE e sinais de disfunção diastólica grau I.

DISCUSSÃo: $R H$ J presente correlaciona-se com a pressão da artéria pulmonar e provavelmente reflete o aumento do volume sanguíneo central.

PALAVRAS-CHAVE: Hipertensão. Veias jugulares/fisiologia. Insuficiência cardíaca.

\section{REFERENCES}

1. Sociedade Brasileira de Cardiologia; Sociedade Brasileira de Hipertensão; Sociedade Brasileira de Nefrologia. VI diretrizes brasileiras de hipertensão. Arq Bras Cardiol. 2010;95(1 Suppl):1-51.

2. Consolim-Colombo FM, Atala MM. Prevenção e tratamento da insuficiência cardíaca no paciente hipertenso. Rev Soc Cardiol Estado 2004;14(1):5567.

3. Mesquita ET, Jorge AJ. Treatment of heart failure with normal ejection fraction. Arq Bras Cardiol. 2010;94(3):414-26.

4. Jorge AJL, Mesquita ET. Insuficiência cardíaca com fração de ejeção normal: estado da arte. Rev SOCERJ. 2008;21(6):409-17.

5. Fiorelli Al, Coelho GHB, Oliveira Junior LL, Oliveira AS. Insuficiência cardíaca e transplante cardíaco. Rev Med (São Paulo). 2008;87(2):105-20.

6. Pasteur W. Note on a new physical sign of tricuspid regurgitation. Lancet. 1885;126(3238):524.

7. Burch GE, Ray CT. Mechanism of the hepatojugular reflux test in congestive heart failure. Am Heart J. 1954;48(3):373-82.

8. Sochowski RA, Dubbin JD, Naqvi SZ. Clinical and hemodynamic assessment of the hepatojugular reflux. Am | Cardiol. 1990;66(12):1002-6.
9. Ducas J, Magder S, McGregor M. Validity of the hepatojugular reflux as a clinical test for congestive heart failure. Am J Cardiol. 1983;52(10):1299303

10. Ommen SR, Nishimura RA, Appleton CP, Miller FA, Oh JK, Redfield MM, et al. Clinical utility of Doppler echocardiography and tissue Doppler imaging in the estimation of left ventricular filling pressures: a comparative simultaneous Doppler-catheterization study. Circulation. 2000;102(15):1788-94.

11. Ewy GA. The abdominojugular test: technique and hemodynamic correlates. Ann Intern Med. 1988;109(6):456-60.

12. Kitzman DW, Little WC, Brubaker PH, Anderson RT, Hundley WG, Marburger $\mathrm{CT}$, et al. Pathophysiological characterization of isolated diastolic heart failure in comparison to systolic heart failure. JAMA. 2002;288(17):2144-50.

13. Butman SM, Ewy GA, Standen JR, Kern KB, Hahn E. Bedside cardiovascular examination in patients with severe chronic heart failure: importance of rest or inducible jugular venous distension. J Am Coll Cardiol. 1993;22(4):968-74. 